\title{
Response of various Planting Dates and Varieties on Performance of China Aster under South Gujarat
}

\author{
T. R. Ahir ${ }^{1 *}$, S. L. Chawla ${ }^{2}$, S. T. Bhatt ${ }^{3}$, Dipal S. Bhatt ${ }^{2}$, G. D. Patel ${ }^{2}$ and R. A. Gurjar
}

${ }^{1}$ Fruit Research Station, Navsari Agricultural University, Gandevi-396 360, Gujarat-India

${ }^{2}$ Department of Floriculture and Landscape Architecture, ASPEE College of Horticulture and Forestry, NAU, Navsari-396 450, Gujarat-India

${ }^{3}$ Horticulture Polytechnic, ASPEE College of Horticulture and Forestry, NAU, Navsari-396 450, Gujarat-India

${ }^{4}$ Department of Horticulture, KVK, NAU, Navsari-396 450, Gujarat-India

*Corresponding author

Keywords

China aster,

Planting dates and varieties

Article Info

\section{Accepted:}

17 January 2021

Available Online:

10 February 2021
Present investigation was carried out to standardize planting dates and suitable varieties of China aster for quality flower production in South Gujarat. The experiment was laid out in split plot design having four levels of planting dates (main plots) and six levels of varieties (sub plots). The twenty four treatment combinations of different planting dates and varieties were replicated four times. Among different treatments of China aster, var. Phule Ganesh White planted on $15^{\text {th }}$ October $\left(\mathrm{P}_{1} \mathrm{~V}_{3}\right)$ recorded maximum plant height and stalk length, weight of 10 flowers while planting of Phule Ganesh Violet on $15^{\text {th }}$ October $\left(\mathrm{P}_{1} \mathrm{~V}_{4}\right)$ recorded maximum plant spread in East-West and North-South directions and number of primary branches. However planting of China aster variety ArkaArchana on $15^{\text {th }}$ October $\left(\mathrm{P}_{1} \mathrm{~V}_{5}\right)$ gave maximum number of flowers per plant, flower yield per plant, per hectare and water uptake per flower.

\section{Introduction}

China aster, Callistephus chinensis (L.) Nees belongs to family Asteraceae and native of China and Europe. The genus Callistephus derived its name from two greek words 'Kalistos' and 'Stephos' meaning 'most beautiful' and 'a crown' respectively. Cassini described the China aster as Callistephus hortensis. It was first named by Linnaeus as Aster chinensis and Nees changed this name to Callistephus chinensis. China aster is a very popular annual flower crop and mainly cultivated for production of cut flowers, loose 
flowers, pot plant and bedding plant purposes in landscape. It is gaining fast popularity in India because of its easy cultural practices, diversity of colours and varied uses. Evolution of aster flowers brought a new range of colours starting from white, rose, red lavender, magenta and blue to their innumerable variations (Desai, 1967). The plants of China aster are erect and attain a maximum height of $60-80 \mathrm{~cm}$ depending upon the genotypes. There is a vast scope of growing China aster for cut flowers and loose flower production in country. But the planting time is vary according to agro climatic conditions. The Kamini variety of China aster has good potential and suitable for loose flower production in Himachal Pradesh (SapnaKaushal et al., 2014). Performance of all varieties is not similar in all climatic conditions. There is no information regarding date of planting and varieties on China aster particularly in South Gujarat conditions hence need was felt to standardize the suitable planting time for cultivation of its varieties in South Gujarat for the commercialization of this crop. Keeping in view the above facts, the present experiment was designed to indentify suitable varieties of China aster and their most favourable planting time for particular variety under agro climatic condition of south Gujarat.

\section{Materials and Methods}

The present experiment was carried out at Floriculture Research Farm, ASPEE College of Horticulture \& Forestry, Navsari Agricultural University, Navsari during the Rabi season of 2018-19 and 2019-20 from August to April months. The experiment was laid out in split plot design having four main plots of planting dates viz., $\mathrm{P}_{1}-15^{\text {th }}$ October, $\mathrm{P}_{2}-1^{\text {st }}$ November, $\mathrm{P}_{3}-16^{\text {th }}$ November and $\mathrm{P}_{4}-1^{\text {st }}$ December and six sub plots of varieties viz., $\mathrm{V}_{1}$-Phule Ganesh Pink, $\mathrm{V}_{2}$-Phule Ganesh Purple, $\mathrm{V}_{3}$-Phule Ganesh White, $\mathrm{V}_{4}$-Phule
Ganesh Violet, $\mathrm{V}_{5}$-Arka Archana and $\mathrm{V}_{6^{-}}$ ArkaKamini. The twenty four treatment combinations of different planting dates and varieties were replicated four times. Healthy, disease free seedlings of uniform size having 3-4 true leaves were used for transplanting on four different planting dates. The seedlings were transplanted with the spacing of $30 \times 30$ $\mathrm{cm}$ to accommodate 28 plants per plot. The transplanting from the nursery to the field was done in the evening hours. Well decomposed farm yard manure (FYM) @ 10 t/ha was added before the transplanting of seedlings and mixed thoroughly in the soil. Nitrogen, phosphorus and potash were applied in the form of urea, single superphosphate and muriate of potash, respectively. Fertilizers were applied at the rate of $200 \mathrm{~kg} \mathrm{~N}, 100 \mathrm{~kg} \mathrm{P}$ and $100 \mathrm{~kg} \mathrm{~K}$ per hectare in China aster with half dose of $\mathrm{N}$ and full dose of $\mathrm{P}$ and $\mathrm{K}$ as a basal dose and remaining $\mathrm{N}$ at 30 days after transplanting. The observations were recorded on various vegetative, flowering and yield parameters.

\section{Results and Discussion}

Effect of planting dates and varieties on vegetative growth character of China aster

It is evident from the data (Table 1) that maximum plant height $(48.83 \mathrm{~cm}$ and 64.59 $\mathrm{cm})$ at 60 and 90 DAT, respectively was recorded in China aster variety Phule Ganesh White transplanted on $15^{\text {th }}$ October $\left(\mathrm{P}_{1} \mathrm{~V}_{3}\right)$. While, maximum plant spread E-W $(40.16 \mathrm{~cm}$ and $48.95 \mathrm{~cm})$, plant spread N-S $(40.61 \mathrm{~cm}$ and $52.84 \mathrm{~cm}$ ) and number of primary branches (13.53 and 13.15)at 60 and 90 DAT, respectively were observed in China aster variety Phule Ganesh Violet transplanted on $15^{\text {th }}$ October $\left(\mathrm{P}_{1} \mathrm{~V}_{4}\right)$ and minimum plant height $(24.76 \mathrm{~cm}$ and $27.63 \mathrm{~cm})$, plant spread E-W $(10.33 \mathrm{~cm}$ and $15.78 \mathrm{~cm}$ ) and plant spread N-S $(11.30 \mathrm{~cm}$ and $16.93 \mathrm{~cm})$ at 60 and 90 DAT, respectively were noted in China aster variety 
ArkaArchana transplanted on $1^{\text {st }}$ December $\left(\mathrm{P}_{4} \mathrm{~V}_{5}\right)$. However, minimum number of primary branches (2.83 and 3.95) at 60 and 90 DAT, respectively was found in China aster variety Phule Ganesh Pink transplanted on $1^{\text {st }}$ December $\left(\mathrm{P}_{4} \mathrm{~V}_{1}\right)$. It might be due to that $15^{\text {th }}$ October planted crop go to maximum time to put up sufficient vegetative growth which was further catalyzed by the superior genotype of variety Phule Ganesh White. These results are in close agreement with the earlier work of Dilta et al., (2007). It may be due to the onset of natural short days which resulted in hastening of reproductive phase. While studying the effect of season on growth and flowering of aster also reported that the plant volume was greatest in the monsoon season.

The variation exhibited by varieties for plant height and spread may be due to differences in their genetic make up and varietal vigor in China aster (Dhemre et al., 1998 and Bajad et al., 2017). This improvement might be due to the reason that $15^{\text {th }}$ October planted crop got maximum time to put up sufficient vegetative growth particularly the more number of branches which was further catalyzed by the genotype of Phule Ganesh Violet. These results are in close agreement with the earlier work of SmitaPakhale et al., (2012) in African marigold and Ismail et al., (2013) in Mexican marigold.

Effect of planting dates and varieties on flowering and quality character of China aster

Data regarding flowering and quality characters, days to first flower opening, $50 \mathrm{per}$ cent flower opening, duration of flowering, flower head diameter, weight of 10 flowers and longevity of flowers were found nonsignificant, except stalk length. The maximum stalk length $(33.83 \mathrm{~cm})$ was recorded in China aster variety Phule Ganesh White transplanted on $15^{\text {th }}$ October $\left(\mathrm{P}_{1} \mathrm{~V}_{3}\right)$ and minimum stalk length $(10.36 \mathrm{~cm})$ was found in China aster variety ArkaArchana transplanted on $1^{\text {st }}$ December $\left(\mathrm{P}_{4} \mathrm{~V}_{5}\right)$ (Table 2).

This could be ascribed to the genetic makeup of variety and favorable climatic conditions because of proper planting time as well during the blooming growth and flowering period. These findings are in accordance with the work of Swaroop et al., (2004) in China aster and Dilta et al., (2005) in chrysanthemum.

\section{Effect of planting dates and varieties on yield character of China aster}

It is clear from the data (Table 3) that maximum number of flowers per plant (62.15), flower yield per plant (189.88 g), yield per plot $(3.53 \mathrm{~kg})$ and yield per hectare (138.52 q) were recorded in China aster variety ArkaArchana transplanted on $15^{\text {th }}$ October $\left(\mathrm{P}_{1} \mathrm{~V}_{5}\right)$ and minimum flowers per plant (21.63), flower yield per plant (49.95 g) and yield per hectare (36.89 q) were recorded in China aster variety ArkaKamini transplanted on $1^{\text {st }}$ December $\left(\mathrm{P}_{4} \mathrm{~V}_{6}\right)$. The more number of flowers were produced when planting was accomplished in mid of October which may be ascribed to the fact that these plants could get sufficient time for putting up more vegetative growth particularly the production of more number of shoots which later on become reproductive. So, they produced comparatively more flowering stems than the later planted crop.

The results are in confirmation with the findings of Dhatt and Kumar (2010) in larkspur. Similar results were found by Nagaraju et al., (2004), Sreenivasulu et al., (2004), Kumar (2005), Dilta et al., (2007) and Bajad et al., (2017) in China aster; Arora et al., (2002) and Vasanthakumar et al., (2015) in gladiolus; Basoli (2009) in chrysanthemum; SmitaPakhale et al., (2012) in marigold and Kumar and Kaur (2000) in phlox. 
Table.1 Effect of different planting dates and varieties of China aster on vegetative parameters at 60 and 90 DAT

\begin{tabular}{|c|c|c|c|c|c|c|c|c|}
\hline \multirow[t]{2}{*}{ Treatments } & \multicolumn{2}{|c|}{ Plant height $(\mathrm{cm})$} & \multicolumn{2}{|c|}{$\begin{array}{c}\text { Plant spread }(\mathrm{cm}) \\
\text { East-West }\end{array}$} & \multicolumn{2}{|c|}{$\begin{array}{l}\text { Plant spread (cm) } \\
\text { North-South }\end{array}$} & \multicolumn{2}{|c|}{$\begin{array}{c}\text { No. of primary } \\
\text { branches }\end{array}$} \\
\hline & $60 \mathrm{DAT}$ & $90 \mathrm{DAT}$ & $60 \mathrm{DAT}$ & $90 \mathrm{DAT}$ & $60 \mathrm{DAT}$ & $90 \mathrm{DAT}$ & $60 \mathrm{DAT}$ & $90 \mathrm{DAT}$ \\
\hline $\mathbf{P}_{1} \mathbf{V}_{1}$ & 45.28 & 57.14 & 27.84 & 34.82 & 27.10 & 35.53 & 8.10 & 8.80 \\
\hline $\mathbf{P}_{1} \mathbf{V}_{2}$ & 42.75 & 59.10 & 27.58 & 37.69 & 30.30 & 37.50 & 10.30 & 11.20 \\
\hline $\mathbf{P}_{1} \mathbf{V}_{3}$ & 48.83 & 64.59 & 37.64 & 48.81 & 37.04 & 43.94 & 8.65 & 9.75 \\
\hline $\mathbf{P}_{1} \mathbf{V}_{4}$ & 47.01 & 61.54 & 40.16 & 48.95 & 40.61 & 52.84 & 13.53 & 13.15 \\
\hline $\mathbf{P}_{1} \mathbf{V}_{5}$ & 31.99 & 47.56 & 25.68 & 34.18 & 26.31 & 32.58 & 12.18 & 12.58 \\
\hline $\mathbf{P}_{1} \mathbf{V}_{6}$ & 36.21 & 49.98 & 20.36 & 25.16 & 18.89 & 23.70 & 10.95 & 10.83 \\
\hline $\mathbf{P}_{2} \mathbf{V}_{1}$ & 41.38 & 51.75 & 24.10 & 30.56 & 22.81 & 30.28 & 7.33 & 7.43 \\
\hline $\mathbf{P}_{2} \mathbf{V}_{2}$ & 39.40 & 50.84 & 24.81 & 33.35 & 27.25 & 35.49 & 9.95 & 10.85 \\
\hline $\mathbf{P}_{2} \mathbf{V}_{3}$ & 44.44 & 58.98 & 30.11 & 42.50 & 33.91 & 42.22 & 8.18 & 9.13 \\
\hline $\mathbf{P}_{2} \mathbf{V}_{4}$ & 39.97 & 52.45 & 35.37 & 45.76 & 36.22 & 45.57 & 11.88 & 12.38 \\
\hline $\mathbf{P}_{2} \mathbf{V}_{5}$ & 27.05 & 36.88 & 20.80 & 29.63 & 19.84 & 27.27 & 10.45 & 11.00 \\
\hline $\mathbf{P}_{2} \mathbf{V}_{6}$ & 33.90 & 41.60 & 17.69 & 22.55 & 16.83 & 21.65 & 9.90 & 10.08 \\
\hline $\mathbf{P}_{3} \mathbf{V}_{1}$ & 31.18 & 41.38 & 19.16 & 25.50 & 19.40 & 27.62 & 4.93 & 6.10 \\
\hline $\mathbf{P}_{3} \mathbf{V}_{2}$ & 34.94 & 45.70 & 20.42 & 27.58 & 18.60 & 30.51 & 8.75 & 10.08 \\
\hline $\mathbf{P}_{\mathbf{3}} \mathbf{V}_{\mathbf{3}}$ & 36.26 & 53.88 & 23.46 & 35.00 & 21.24 & 38.64 & 7.75 & 8.05 \\
\hline $\mathbf{P}_{3} \mathbf{V}_{4}$ & 34.44 & 47.34 & 28.81 & 37.15 & 24.08 & 38.94 & 10.15 & 11.53 \\
\hline $\mathbf{P}_{3} \mathbf{V}_{5}$ & 25.02 & 29.50 & 16.76 & 21.00 & 17.79 & 23.82 & 8.75 & 9.68 \\
\hline $\mathbf{P}_{3} \mathbf{V}_{6}$ & 26.81 & 36.69 & 14.97 & 19.16 & 15.35 & 20.58 & 9.20 & 9.65 \\
\hline $\mathbf{P}_{4} \mathbf{V}_{1}$ & 27.27 & 31.03 & 12.28 & 22.68 & 16.56 & 24.71 & 2.83 & 3.95 \\
\hline $\mathbf{P}_{4} \mathbf{V}_{2}$ & 28.17 & 33.71 & 16.44 & 21.85 & 14.54 & 21.51 & 5.35 & 6.68 \\
\hline $\mathbf{P}_{4} \mathbf{V}_{3}$ & 30.33 & 40.65 & 17.20 & 24.13 & 15.15 & 23.19 & 6.93 & 6.45 \\
\hline $\mathbf{P}_{4} \mathbf{V}_{4}$ & 28.35 & 34.05 & 20.89 & 28.09 & 16.11 & 22.54 & 8.40 & 9.83 \\
\hline $\mathbf{P}_{4} \mathbf{V}_{5}$ & 24.76 & 27.63 & 10.33 & 15.78 & 11.30 & 16.93 & 8.08 & 8.98 \\
\hline $\mathrm{P}_{4} \mathrm{~V}_{6}$ & 29.38 & 34.63 & 12.96 & 18.35 & 13.09 & 19.25 & 8.43 & 8.88 \\
\hline S.Em. \pm & 1.57 & 1.65 & 0.92 & 1.04 & 0.80 & 1.14 & 0.43 & 0.43 \\
\hline C.D. at $5 \%$ & 4.39 & 4.60 & 2.56 & 2.91 & 2.24 & 3.20 & 1.19 & 1.20 \\
\hline C.V.\% V & 13.38 & 10.84 & 11.89 & 10.04 & 10.46 & 11.10 & 14.51 & 13.53 \\
\hline
\end{tabular}


Table.2 Effect of different planting dates and varieties of China aster on flowering and quality character

\begin{tabular}{|c|c|c|c|c|c|c|c|}
\hline Treatments & $\begin{array}{c}\text { Days to } \\
\text { first } \\
\text { flower } \\
\text { opening }\end{array}$ & $\begin{array}{c}50 \% \\
\text { flower } \\
\text { opening } \\
\text { (days) }\end{array}$ & $\begin{array}{c}\text { Duration } \\
\text { of } \\
\text { flowering } \\
\text { (days) }\end{array}$ & $\begin{array}{c}\text { Flower } \\
\text { head } \\
\text { diameter } \\
(\mathbf{c m})\end{array}$ & $\begin{array}{c}\text { Stalk } \\
\text { length } \\
(\mathrm{cm})\end{array}$ & $\begin{array}{c}\text { Weight } \\
\text { of } 10 \\
\text { flowers } \\
\text { (g) }\end{array}$ & $\begin{array}{l}\text { Longevity } \\
\text { of flowers } \\
\text { (days) }\end{array}$ \\
\hline $\mathbf{P}_{1} \mathbf{V}_{1}$ & 70.45 & 75.13 & 31.40 & 7.13 & 25.19 & 40.18 & 11.43 \\
\hline $\mathbf{P}_{1} \mathbf{V}_{2}$ & 71.30 & 75.88 & 32.70 & 7.45 & 33.51 & 36.80 & 10.83 \\
\hline$P_{1} V_{3}$ & 72.05 & 76.75 & 46.80 & 7.66 & 33.83 & 42.23 & 11.38 \\
\hline $\mathbf{P}_{1} \mathbf{V}_{4}$ & 69.38 & 74.00 & 38.10 & 6.77 & 28.50 & 33.13 & 10.08 \\
\hline $\mathbf{P}_{1} \mathbf{V}_{5}$ & 66.83 & 71.63 & 41.75 & 6.12 & 20.83 & 34.12 & 11.20 \\
\hline $\mathbf{P}_{1} \mathbf{V}_{6}$ & 68.28 & 72.88 & 36.49 & 6.32 & 24.25 & 30.98 & 11.28 \\
\hline $\mathbf{P}_{2} \mathbf{V}_{1}$ & 68.33 & 73.13 & 28.50 & 6.54 & 22.61 & 38.48 & 10.78 \\
\hline $\mathbf{P}_{2} \mathbf{V}_{2}$ & 69.05 & 73.88 & 30.93 & 6.64 & 29.96 & 34.18 & 10.45 \\
\hline $\mathbf{P}_{2} \mathbf{V}_{3}$ & 71.38 & 76.25 & 41.75 & 6.84 & 30.39 & 40.83 & 10.98 \\
\hline $\mathbf{P}_{2} \mathbf{V}_{4}$ & 62.83 & 67.75 & 35.20 & 6.43 & 27.26 & 31.75 & 9.83 \\
\hline $\mathbf{P}_{2} \mathbf{V}_{5}$ & 59.58 & 64.38 & 39.05 & 5.72 & 14.11 & 31.40 & 11.00 \\
\hline $\mathbf{P}_{2} \mathbf{V}_{6}$ & 61.65 & 66.50 & 33.93 & 6.11 & 19.41 & 28.46 & 11.08 \\
\hline $\mathbf{P}_{3} \mathbf{V}_{1}$ & 64.10 & 68.88 & 24.75 & 6.12 & 19.20 & 37.12 & 10.20 \\
\hline $\mathbf{P}_{\mathbf{3}} \mathbf{V}_{\mathbf{2}}$ & 65.83 & 70.63 & 26.90 & 6.34 & 22.01 & 30.47 & 9.80 \\
\hline $\mathbf{P}_{\mathbf{3}} \mathbf{V}_{\mathbf{3}}$ & 68.25 & 73.25 & 38.18 & 6.74 & 25.75 & 39.17 & 10.48 \\
\hline $\mathbf{P}_{3} \mathbf{V}_{4}$ & 61.30 & 66.13 & 31.95 & 5.82 & 20.11 & 30.51 & 9.38 \\
\hline $\mathbf{P}_{3} \mathbf{V}_{5}$ & 57.98 & 62.88 & 33.43 & 5.35 & 11.34 & 28.75 & 9.88 \\
\hline $\mathbf{P}_{3} \mathbf{V}_{6}$ & 60.05 & 64.75 & 30.93 & 5.73 & 14.03 & 27.19 & 10.00 \\
\hline $\mathbf{P}_{4} \mathbf{V}_{1}$ & 57.45 & 62.13 & 21.43 & 5.79 & 13.67 & 38.24 & 9.85 \\
\hline $\mathbf{P}_{4} \mathbf{V}_{2}$ & 59.08 & 63.88 & 22.63 & 5.96 & 19.73 & 29.70 & 9.23 \\
\hline $\mathbf{P}_{4} \mathbf{V}_{3}$ & 61.80 & 66.63 & 33.85 & 6.53 & 23.13 & 34.29 & 10.00 \\
\hline $\mathbf{P}_{4} \mathbf{V}_{4}$ & 57.15 & 62.00 & 30.20 & 5.57 & 17.25 & 29.35 & 8.90 \\
\hline $\mathbf{P}_{4} \mathbf{V}_{5}$ & 47.85 & 52.50 & 31.35 & 5.25 & 10.36 & 30.19 & 9.53 \\
\hline $\mathbf{P}_{4} \mathbf{V}_{6}$ & 50.45 & 55.25 & 28.45 & 5.46 & 13.20 & 25.56 & 9.65 \\
\hline S.Em. \pm & 1.91 & 1.97 & 0.88 & 0.18 & 0.88 & 1.25 & 0.36 \\
\hline C.D. at $5 \%$ & NS & NS & NS & NS & 2.46 & NS & NS \\
\hline C.V .\% V & 9.00 & 8.66 & 8.01 & 8.38 & 12.12 & 11.12 & 10.46 \\
\hline
\end{tabular}


Table.3 Effect of different planting dates and varieties of China aster on yield character

\begin{tabular}{|c|c|c|c|}
\hline Treatments & No. of flowers/plant & $\begin{array}{c}\text { Flower } \\
\text { yield/plant (g) }\end{array}$ & $\begin{array}{c}\text { Flower } \\
\text { yield/ha }(q)\end{array}$ \\
\hline $\mathbf{P}_{1} \mathbf{V}_{1}$ & 43.73 & 155.43 & 109.78 \\
\hline $\mathbf{P}_{1} \mathbf{V}_{2}$ & 35.55 & 115.09 & 80.98 \\
\hline $\mathbf{P}_{1} \mathbf{V}_{3}$ & 34.08 & 124.43 & 86.85 \\
\hline $\mathbf{P}_{1} \mathbf{V}_{4}$ & 33.18 & 95.94 & 68.13 \\
\hline $\mathbf{P}_{1} \mathbf{V}_{5}$ & 62.15 & 189.88 & 138.52 \\
\hline $\mathbf{P}_{1} \mathbf{V}_{6}$ & 29.15 & 82.58 & 60.91 \\
\hline $\mathbf{P}_{2} \mathbf{V}_{1}$ & 37.35 & 128.90 & 91.20 \\
\hline $\mathbf{P}_{2} \mathbf{V}_{2}$ & 33.00 & 102.99 & 72.56 \\
\hline $\mathbf{P}_{2} \mathbf{V}_{3}$ & 32.18 & 113.99 & 79.53 \\
\hline $\mathbf{P}_{2} \mathbf{V}_{4}$ & 27.48 & 77.49 & 54.99 \\
\hline $\mathbf{P}_{2} \mathbf{V}_{5}$ & 52.40 & 148.60 & 108.34 \\
\hline $\mathbf{P}_{2} \mathbf{V}_{6}$ & 25.05 & 65.54 & 48.37 \\
\hline $\mathbf{P}_{\mathbf{3}} \mathbf{V}_{\mathbf{1}}$ & 30.50 & 100.62 & 71.14 \\
\hline $\mathbf{P}_{3} \mathbf{V}_{2}$ & 29.90 & 79.62 & 56.14 \\
\hline $\mathbf{P}_{\mathbf{3}} \mathbf{V}_{\mathbf{3}}$ & 28.33 & 96.69 & 67.52 \\
\hline $\mathbf{P}_{3} \mathbf{V}_{4}$ & 24.20 & 65.63 & 46.59 \\
\hline $\mathbf{P}_{3} \mathbf{V}_{5}$ & 43.25 & 111.57 & 81.42 \\
\hline $\mathbf{P}_{3} \mathbf{V}_{6}$ & 25.40 & 61.64 & 45.47 \\
\hline $\mathbf{P}_{4} \mathbf{V}_{1}$ & 25.50 & 87.62 & 61.85 \\
\hline $\mathbf{P}_{4} \mathbf{V}_{2}$ & 24.70 & 66.06 & 46.47 \\
\hline $\mathbf{P}_{4} \mathbf{V}_{3}$ & 25.13 & 76.47 & 53.36 \\
\hline $\mathbf{P}_{4} \mathbf{V}_{4}$ & 25.73 & 66.29 & 47.01 \\
\hline $\mathbf{P}_{4} \mathbf{V}_{5}$ & 35.30 & 95.80 & 69.89 \\
\hline $\mathbf{P}_{4} \mathbf{V}_{6}$ & 21.63 & 49.95 & 36.89 \\
\hline S.Em. \pm & 1.31 & 5.64 & 4.06 \\
\hline C.D. at $5 \%$ & 3.65 & 15.77 & 11.36 \\
\hline C.V.\% V & 11.79 & 17.10 & 17.26 \\
\hline
\end{tabular}


Table.4 Effect of different planting dates and varieties of China aster on post harvest character

\begin{tabular}{|c|c|c|c|c|}
\hline Treatments & Shelf life (days) & Vase life (days) & $\begin{array}{c}\text { Water } \\
\text { uptake/flower } \\
(\mathrm{ml})\end{array}$ & $\begin{array}{l}\text { Fresh weight } \\
\text { retention (g) }\end{array}$ \\
\hline $\mathbf{P}_{1} \mathbf{V}_{1}$ & 3.68 & 7.58 & 4.34 & 33.15 \\
\hline $\mathbf{P}_{1} \mathbf{V}_{2}$ & 2.88 & 6.88 & 3.97 & 29.91 \\
\hline $\mathbf{P}_{1} \mathbf{V}_{3}$ & 3.38 & 7.38 & 4.17 & 35.15 \\
\hline $\mathbf{P}_{1} \mathbf{V}_{4}$ & 2.73 & 6.73 & 3.85 & 26.72 \\
\hline $\mathbf{P}_{1} \mathbf{V}_{5}$ & 3.00 & 7.00 & 4.40 & 27.86 \\
\hline $\mathbf{P}_{1} \mathbf{V}_{6}$ & 3.18 & 7.18 & 3.82 & 25.09 \\
\hline $\mathbf{P}_{2} \mathbf{V}_{1}$ & 2.83 & 6.85 & 4.02 & 29.71 \\
\hline $\mathbf{P}_{2} \mathbf{V}_{2}$ & 2.43 & 6.43 & 3.77 & 25.76 \\
\hline $\mathbf{P}_{2} \mathbf{V}_{3}$ & 3.23 & 7.23 & 4.05 & 32.02 \\
\hline $\mathbf{P}_{2} \mathbf{V}_{4}$ & 2.38 & 6.38 & 3.66 & 23.74 \\
\hline $\mathbf{P}_{2} \mathbf{V}_{5}$ & 2.75 & 6.75 & 4.16 & 23.99 \\
\hline $\mathbf{P}_{2} \mathbf{V}_{6}$ & 3.03 & 7.05 & 3.67 & 21.47 \\
\hline $\mathbf{P}_{3} \mathbf{V}_{1}$ & 2.40 & 6.43 & 3.77 & 27.15 \\
\hline $\mathbf{P}_{3} \mathbf{V}_{2}$ & 2.15 & 6.15 & 3.61 & 21.62 \\
\hline $\mathbf{P}_{3} \mathbf{V}_{3}$ & 2.73 & 6.73 & 3.85 & 29.02 \\
\hline $\mathbf{P}_{3} \mathbf{V}_{4}$ & 2.05 & 6.03 & 3.50 & 21.41 \\
\hline $\mathbf{P}_{3} \mathbf{V}_{5}$ & 2.28 & 6.28 & 3.79 & 20.73 \\
\hline $\mathbf{P}_{3} \mathbf{V}_{6}$ & 2.33 & 6.33 & 3.53 & 19.43 \\
\hline $\mathbf{P}_{4} \mathbf{V}_{1}$ & 2.23 & 6.25 & 3.66 & 25.13 \\
\hline $\mathbf{P}_{4} \mathbf{V}_{2}$ & 1.83 & 5.80 & 3.44 & 18.90 \\
\hline $\mathbf{P}_{4} \mathbf{V}_{3}$ & 2.25 & 6.25 & 3.60 & 22.57 \\
\hline $\mathbf{P}_{4} \mathbf{V}_{4}$ & 1.48 & 5.48 & 3.37 & 18.46 \\
\hline $\mathbf{P}_{4} \mathbf{V}_{5}$ & 1.88 & 5.90 & 3.70 & 19.45 \\
\hline $\mathbf{P}_{4} \mathbf{V}_{6}$ & 2.25 & 6.25 & 3.38 & 16.20 \\
\hline S.Em. \pm & 0.12 & 0.16 & 0.05 & 0.99 \\
\hline C.D. at $5 \%$ & NS & NS & 0.13 & NS \\
\hline C.V .\% V & 13.66 & 7.19 & 3.69 & 11.88 \\
\hline
\end{tabular}

Effect of planting dates and varieties on post harvest character of China aster

In post harvest parameters viz., shelf life, vase life and fresh weight retention were found non-significant, except water uptake per flower (Table 4).

The maximum water uptake per flower (4.40 ml) was observed in China aster variety ArkaArchana transplanted on $15^{\text {th }}$ October
$\left(\mathrm{P}_{1} \mathrm{~V}_{5}\right)$ and minimum water uptake per flower $(3.37 \mathrm{ml})$ was observed in China aster variety Phule Ganesh Violet transplanted on $1^{\text {st }}$ December $\left(\mathrm{P}_{4} \mathrm{~V}_{4}\right)$.

It may be due to superiority of genetical make up along with the vigorous vegetative growth has good capacity to higher water uptake. Similar results were found by Chowdhuri et al., (2016), Kumar (2010), Sultan and Nassour (2019) in China aster. 


\section{References}

Arora, J. S., Misra, R. L., Singh, K., Bhattacharya, S. K. (2002). Gladiolus, Project Co-ordination Report, All India Co-ordinated Research Project on Floriculture, New Delhi, India.

Bajad, A, A., Sharma, B. P., Gupta, Y. C., Dilta, B. S. and Gupta, R. K. (2017). Effect of different planting times and mulching materials on flower quality and yield of China aster cultivars. $J$. Pharmacognosy and Phytochemistry, 6(6): 1321-1326.

Basoli, M. (2009). Studies on the effect of planting dates on growth and flowering of chrysanthemum (Dendranthema grandiflora Tzvelev.). M.Sc. Thesis submitted to Dr. Y. S. Parmar University of Horticulture and Forestry, Nauni, Solan (H.P).

Chowdhuri, T. K., Rout, B., Sadhukhan, R. and Mondal, T. (2016). Performance of evaluation of different varieties of China aster (Callistephus chinesis L Ness.) in sub-tropical belt of West Bengal. Inter. J. Pharmaceutical Sci. Invention, 5(8): 15-18.

Desai, B. L. (1967). Seasonal Flowers. ICAR, New Delhi. pp: 237.

Dhatt, K. K and Kumar, R. (2010). Effect of planting time and growth regulators on growth and seed quality parameters of larkspur. J. Ornam. Hort., 13(1): 5054.

Dhemere, J. K., Shirsath, N. S., Nagaphade, A. S. and Gondhali, R. V. (1998). Effects of different planting densities and seasons on growth and flower quality of China aster. J. Maharashtra Agril. Univ., 23(2): 118-120.

Dilta, B. S., Sharma, Y. D. and Verda, V. K. (2005). Evaluation of chrysanthemum cultivars under sub-tropical region of Himachal Pradesh. J. Ornam. Hort., 8(2): 149-151.
Dilta, B. S., Gupta, Y. C. and Sharma, P. (2007). Effect of different planting dates on performance of China aster (Callistephus chinesisNees.) varieties. The Asian J. Hort., 2(2): 245-248.

Ismail, F. S., Kandeel, A. M., Ibrahim, K. A. and Omer, A. E. (2013). Effect of planting date and plant spacing on growth, yield and essential oil of Mexican marigold (TageteslucidaL.) cultivated in Egypt. J. Appl. Sci. Res., 9(1): 330-340.

Kumar, S. (2005). Evaluation of cultivars, planting dates and $\mathrm{GA}_{3}$ on flowering and seed field of China aster (Callistephus chinensis Nees.) varieties. M.Sc. Thesis submitted to Dr. Y. S. Parmar University of Horticulture and Forestry, Nauni, Solan.

Kumar, S. (2010). Studies on the effect of integrated nutrient management on growth, yield and vase life of China aster (Callistephus chinensis Nees). M.Sc. Thesis, Submitted to Agricultural Research Institute, Andhra Pradesh Horticultural University, Rajendranagar, Hyderabad, AP, India.

Kumar, R. and Kaur, K. (2000). Effect of planting time and cultivars on growth, flowering and seed yield in phlox (Phlox drumondii). Seed Research, 28(1): 23-26.

Nagaraju, D., Reddy, B. S., Patil, R. T., Gangadharappa, P. M. and Kulkarni, B. S. (2004). Effect of dates of planting on flowering and flower quality of China aster (Callistephus chinensis Nees.) cv. Kamini. J. Ornam. Hort., 7(3-4): 132-134.

SapnaKaushal; Dilta, B.S., Chaudhary, S. V. S., Sharma, B. P. and Gupta, Y. C. (2014). Effect of planting dates on growth and flowering of China aster [Callistephus chinensis (L) Nees]. 
Inter. J. Farm Sciences,4(1): 60-71.

SmitaPakhale; Golliwar, V. J., Panchbhai, D. M., Prarthana, J. and Deshmane, S. (2012). Response of African marigold varieties to different planting time on growth and yield under Vidharba conditions (Maharastra, India). J. Soils Crops, 22(1): 183-187.

Sreenivasulu, G. B., Balaji, S. K., Reddy, B. S. and Adiga, J. D. (2004). Yield and quality parameters as influenced by seasons and genotypes in China aster. J. Ornam. Hort., 7(3-4): 122-124.

Sultan, M. and Nassour, M. (2019). Evaluation of some genotypes of China aster [Callistephus chinensis
(L.) Nees.] under the condition of Syrian coast-Lattakia. Int. J. Agric. Envir. Sci., 6(3): 24-27.

Swaroop, K., Singh, K. P., Saxena, N. K and Singh, K. P. (2004). Evaluation of China aster varieties under Delhi conditions. J. Ornam. Hort., 7(1): 127128.

Vasanthakumar, K., Bezu, T. and Bekele, A. (2015). Response of varieties and planting dates on growth and flowering of gladiolus (Gladiolus grandiflorus Andrews) under the ecological conditions of Haramaya University, Eastern Ethiopia. J. Hort. Forestry, 7(5): 112-117.

\section{How to cite this article:}

Ahir, T. R., S. L. Chawla, S. T. Bhatt, Dipal S. Bhatt, G. D. Patel and Gurjar, R. A. 2021. Response of various Planting Dates and Varieties on Performance of China Aster under South Gujarat. Int.J.Curr.Microbiol.App.Sci. 10(02): 2025-2033. doi: https://doi.org/10.20546/ijcmas.2021.1002.242 